\title{
Adult Grade II Meningioma
}

National Cancer Institute

\section{Source}

National Cancer Institute. Adult Grade II Meningioma. NCI Thesaurus. Code C71304.

A grade II meningioma that occurs during adulthood. 